\title{
Grazing by the heterotrophic dinoflagellate Protoperidinium steinii on a Ceratium bloom
}

\author{
Christine D. Olseng, Lars-Johan Naustvoll, Eystein Paasche*
}

Section for Marine Botany, Department of Biology, University of Oslo, PO Box 1069, Blindern, 0316 Oslo, Norway

\begin{abstract}
Variations in heterotrophic dinoflagellate populations at a station in the inner Oslofjord, Norway, were studied by sampling at ca $4 \mathrm{~d}$ intervals. Cells were concentrated from 11 samples by filtration before being counted in an inverted microscope. Additional data include autotrophic carbon biomass estimates based on microscopy of the phytoplankton, chlorophyll a (chl a) concentrations, and hydrography. A modest ( 2 to $4 \mu \mathrm{g} \mathrm{chl} \mathrm{a} \mathrm{l}^{-1}$ ) diatom bloom in September was followed by a large (up to

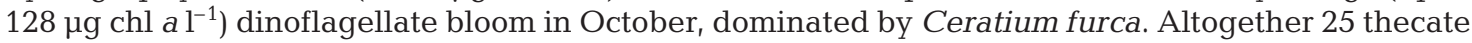
heterotrophic dinoflagellate species were recorded in this study. Their total biomass at all times was $<1 \%$ of that of the autotrophic phytoplankton. Coinciding with the Ceratium bloom, there was a marked growth in Protoperidinium steinii, with cell numbers reaching $>2000$ cells $^{-1}$. P. pyriforme, $P$. brevipes, $P$. curtipes, and Oblea rotunda showed more modest increases, while no significant response was seen in any of the other 20 heterotrophic dinoflagellates. In incubated plankton samples, we recorded 81 instances of $P$. steinii feeding on $C$. furca or on other dinoflagellates. Our study confirms previous laboratory findings suggesting that $P$. steinii belongs to the limited selection of Protoperidinium species capable of exploiting dinoflagellate prey in the natural environment.
\end{abstract}

KEY WORDS: Oslofjord - Heterotrophic dinoflagellates · Protoperidinium steinii • Grazing • Ceratium furca

\section{INTRODUCTION}

Heterotrophic dinoflagellates are nearly always present in marine plankton, and are sometimes quantitatively important as grazers in the microplankton (20 to $200 \mu \mathrm{m}$ ) fraction (e.g. Hansen 1991, Lessard 1991, Archer et al. 1996). They possess highly specialized feeding mechanisms. Members of Protoperidinium, the largest heterotrophic genus within the peridinioid dinoflagellates, acquire their food by means of a pallium; a pseudopod produced by the cell and enabling it to digest plankton algae of its own size, or even considerably larger ones (review by Hansen \& Calado 1999). Smaller objects, such as 'naked' nanoplankton flagellates, are generally not captured by Protoperidinium. While the majority of Protoperidinium species

*Corresponding author. E-mail: e.paasche@bio.uio.no appear to be diatom grazers, some can utilize, and may even require, dinoflagellate prey (review by Jeong 1999). In a pioneering study, Jacobson \& Anderson (1986) noted that $P$. pyriforme cells differed from those of 14 other Protoperidinium species by preferentially capturing autotrophic dinoflagellates rather than diatoms in their pallium. Subsequent laboratory experiments confirmed that food requirements in this genus may be quite specific. Among the relatively few Protoperidinium species that have been brought into culture so far, only P. cf. divergens and P. crassipes (Jeong \& Latz 1994), and recently P. steinii (Naustvoll 2000), have been shown to grow better on dinoflagellate prey than on diatom prey.

More indirect evidence of specific dinoflagellate prey requirements can be obtained by studying shifts in natural populations associated with biomass fluctuations and species successions in the phytoplankton (e.g. Hansen 1991, Nakamura et al. 1995, 1996, Tise- 
lius \& Kuylenstierna 1996, Matsuyama et al. 1999). This approach was used in a recent investigation of Protoperidinium species in the inner Oslofjord, based on approximate monthly sampling through $1 \mathrm{yr}$ (Kjæret et al. 2000). The present study from the same area made use of much more closely repeated sampling, carried out over 2 mo in the autumn during which a modest bloom consisting mainly of the diatom Pseudo-nitzschia pseudodelicatissima was succeeded by a large bloom dominated by the dinoflagellate Ceratium furca. Our goal was to see if close sampling combined with observations of live samples could provide more conclusive evidence of predator-prey relationships involving Protoperidinium spp.

\section{MATERIALS AND METHODS}

The material was collected in the inner Oslofjord at or near the station Nakkholmen $\left(59^{\circ} 53^{\prime} \mathrm{N}, 10^{\circ} 41^{\prime} \mathrm{E}\right)$ at time intervals of 2 to $7 \mathrm{~d}$, from September 7 to November 1, 2000. Data on water temperature and salinity were obtained by means of a mini-STD probe. Sampling for chlorophyll a ( $\mathrm{chl}$ a) was carried out by Niskin bottle casts from the surface to $20 \mathrm{~m}$ depth. The samples were filtered onto Whatman GF/C glass fiber filters (pore size ca $1 \mu \mathrm{m}$ ) and extracted with $90 \%$ acetone according to Strickland \& Parsons (1972) for subsequent analysis in a Turner Designs TD-700 fluorometer. Samples for quantitative microscopy and for observations on live plankton were taken from $2 \mathrm{~m}$ depth, supplemented by horizontal net-hauls. Diatoms in formaldehyde-preserved samples were counted in $2 \mathrm{ml}$ sedimentation chambers on an inverted microscope. Thecate autotrophic and heterotrophic dinoflagellates larger than $20 \mu \mathrm{m}$ were counted in samples concentrated by filtration as described by Kjæret et al. (2000). Essentially, this involved draining a $1000 \mathrm{ml}$ water sample through a small piece of $20 \mu \mathrm{m}$ mesh plankton net, and resuspending the collected material in a small volume of seawater containing formaldehyde, with Calcofluor White M2R added for visualization of the dinoflagellate thecae by epifluorescence (Fritz \& Triemer 1985). The suspension was then distributed into $2 \mathrm{ml}$ sedimentation chambers for counting on an inverted epifluorescence microscope. Dinoflagellates smaller than $30 \mu \mathrm{m}$, mainly the heterotroph Oblea rotunda and the autotroph Prorocentrum micans, were probably not quantitatively retained by the $20 \mu \mathrm{m}$ mesh. Specific carbon biomasses were computed assuming the same cell volumes as in previous investigations in the Oslofjord (see Kjæret et al. 2000), using the equation of Strathmann (1967) for diatoms and those of Menden-Deuer \& Lessard (2000) for autotrophic and heterotrophic dinoflagellates. The stand- ing stock of each species was then calculated as the product of cell density (cells $\mathrm{l}^{-1}$ ) and cell carbon (pg C cell $^{-1}$ ), and the products were summed to give total carbon biomass ( $\mu \mathrm{g} \mathrm{C}^{-1}$ ) for each species or group. The biomass values do not express total autotrophic standing stock, as the microscopic counts did not include non-diatom cells smaller than $20 \mu \mathrm{m}$ such as 'naked' flagellates and cyanobacteria.

On all sampling dates, live material was collected for monitoring of heterotrophic dinoflagellate grazing. Unconcentrated samples from $2 \mathrm{~m}$ depth were transferred to cell culture flasks (Costar, $73 \mathrm{ml}$ capacity) which were incubated on a plankton wheel rotating at ca $2 \mathrm{rpm}$, in a temperature-controlled room at $11^{\circ} \mathrm{C}$, under continuous illumination of $3 \mu \mathrm{mol}$ photons $\mathrm{m}^{-2}$ $\mathrm{s}^{-1}$. The samples were examined daily for up to $2 \mathrm{wk}$ in a Nikon Eclipse TE300 inverted microscope. Grazing events were documented on Kodak EliteChrome 400 film by means of a Nikon Fe 10 camera, for subsequent electronic scanning.

\section{RESULTS}

Salinity at 2 m depth dropped from 23.5 early in September to ca 22 on October 13, and then quite abruptly to ca 18 during the following few days (Fig. 1). This latter event was in all likelihood caused by outflow from land following heavy rainfall on October 10, 11, and 12. Precipitation during this $3 \mathrm{~d}$ period corresponded to the amount normally received in the whole month of October (data from The Norwegian Meteorological Institute). Temperature at $2 \mathrm{~m}$ depth showed a gradual decline from ca $16.5^{\circ} \mathrm{C}$ at the beginning of the sampling period to ca $10^{\circ} \mathrm{C}$ at the end (data not shown). The chlorophyll data (Fig. 2) indicate a small bloom of 2 to $4 \mu \mathrm{g} \mathrm{chl} \mathrm{a} \mathrm{l}^{-1}$ in the uppermost $4 \mathrm{~m}$ layer from September 21 to 28. A much heavier bloom was observed in the same layer from October 16, with maximum values of $128 \mu \mathrm{g} \mathrm{chl} \mathrm{a} \mathrm{l}^{-1}$ at $0 \mathrm{~m}$ depth on October 20 and $81 \mu \mathrm{g} \mathrm{chl} \mathrm{a} \mathrm{l}^{-1}$ at $2 \mathrm{~m}$ depth on October 23. The average chlorophyll concentration in the 0 to $4 \mathrm{~m}$ layer increased by a factor of 26 from October 13 to October 16. This increase is much too large to be explained by local algal growth. We conclude that it was due to advection of a different water mass. Freshwater outflow occasioned by the rainfall a few days earlier was the likely reason for this, as already suggested by the salinity data.

The carbon biomass standing stocks of the most important species or groups of primary producers are shown in Table 1. Even though these data may not describe a succession in the strict sense, they indicate a development from a modest diatom bloom, from September 21 to 28 , to a massive dinoflagellate bloom from 
October 16 onwards. The diatom bloom was composed mainly of Pseudo-nitzschia pseudodelicatissima, while the dinoflagellate bloom was dominated by Ceratium species, C. furca forming 80 to $95 \%$ of Ceratium biomass as well as of Ceratium cell number at any time. The ratio of calculated autotrophic carbon biomass to chlorophyll concentration at $2 \mathrm{~m}$ depth during both blooms was mostly of the order of 20 to $30 \mathrm{~g} \mathrm{C} \mathrm{g}$ chl $a^{-1}$. This is somewhat low, particularly for dinoflagellates, as was to be expected from the non-inclusion of small autotrophic algae in our cell counts (see 'Materials and methods').

The total carbon biomass of thecate heterotrophic dinoflagellates (Table 2) was insignificant compared to the calculated autotrophic biomass (Table 1), amounting to, at most, $1 \%$ of the latter during either bloom period. The maximum cell counts of thecate heterotrophic dinoflagellate species during the Pseudo-nitzschia and Ceratium blooms are listed in Table 3. Throughout the study, the majority of heterotrophic dinoflagellates were present in small and randomly fluctuating numbers, typically $<50$ cells $1^{-1}$. An exception was formed by Protoperidinium steinii, the cell numbers of which declined dur-

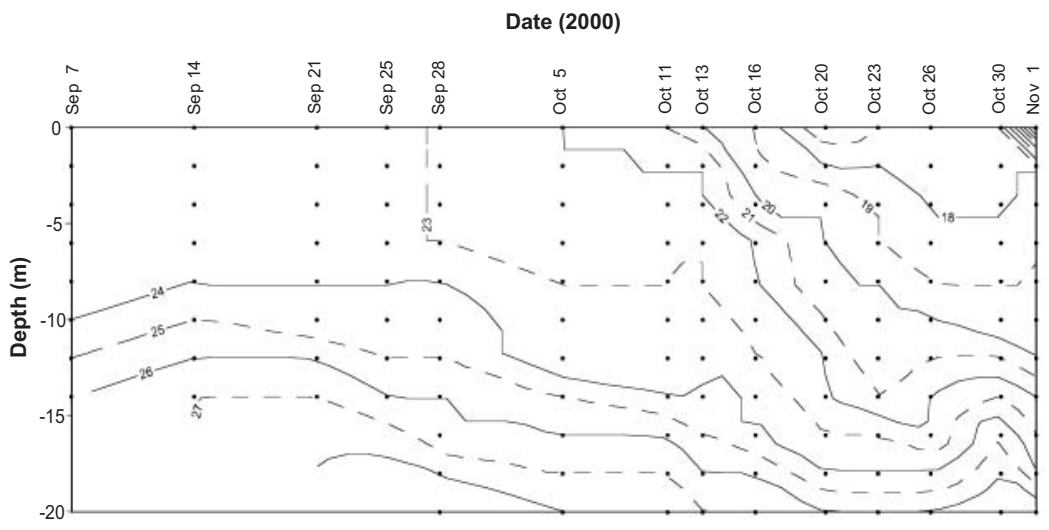

Fig. 1. Variations in salinity in the upper $20 \mathrm{~m}$ at the sampling station

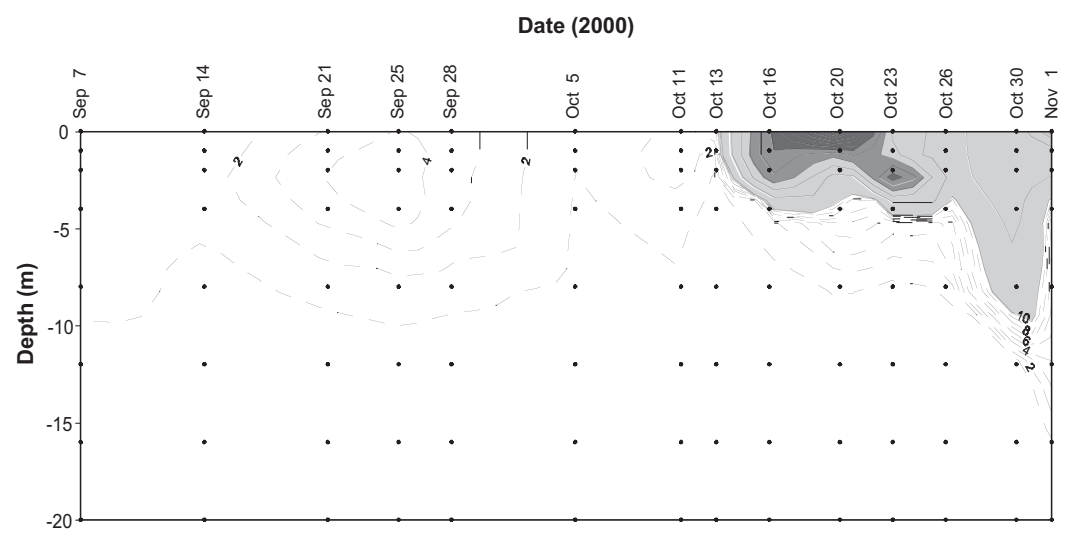

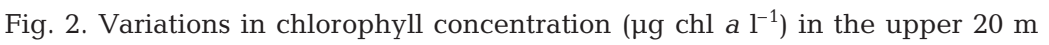
at the sampling station ing September and then increased

markedly during the Ceratium bloom to a maximum of $>2000$ cells $\mathrm{l}^{-1}$ at the end of October (Fig. 3A). Increases were also seen in $P$. pyriforme (Fig. 3A), and to a lesser extent in $P$. brevipes and $P$. curtipes (Table 3); these 3 species were not recorded in September. During the Ceratium bloom, P. steinii made up 55 to $73 \%$ of thecate heterotrophic dinoflagellate cell numbers and 20 to $51 \%$ of the corresponding biomass (Table 2). Regression analysis (using square-root- transformed cell numbers for the whole sampling period) demonstrated a significant correlation between $P$. steinii and $C$. furca abundances $\left(\mathrm{r}^{2}=0.60 ; \mathrm{p}=0.001\right)$. The only other heterotrophic dinoflagellate responding markedly to the dinoflagellate bloom situation was Oblea rotunda (Table 3).

In terms of cumulate numbers throughout the sampling period, Protoperidinium divergens and P. pallidum were next in importance after P. steinii, P. pyri-

Table 1. Carbon biomass $\left(\mu \mathrm{g} \mathrm{Cl}^{-1}\right.$ ) of the most important categories of autotrophic microplankton algae at $2 \mathrm{~m}$ depth

\begin{tabular}{|c|c|c|c|c|c|c|c|c|c|c|c|c|c|c|}
\hline Species or group & Sep 7 & Sep 14 & Sep 21 & Sep 25 & Sep 28 & Oct 5 & Oct 11 & Oct 13 & Oct 16 & Oct 20 & Oct 23 & Oct 26 & Oct 30 & Nov 1 \\
\hline Ceratium furca & 7.2 & 3.5 & 1.3 & 0.3 & 0.3 & 1.1 & 40.8 & 10.5 & 791.2 & 294.4 & 331.0 & 300.3 & 697.2 & 431.8 \\
\hline Ceratium spp. & 1.2 & 0.3 & 0.1 & 0.0 & 0.0 & 0.1 & 3.1 & 0.7 & 105.2 & 76.9 & 12.9 & 21.2 & 65.4 & 74.9 \\
\hline Dinophysis spp. & 1.3 & 0.5 & 1.1 & 0.6 & 0.7 & 0.1 & 3.9 & 2.7 & 102.8 & 37.6 & 26.1 & 79.2 & 62.0 & 46.8 \\
\hline Prorocentrum micans & 6.8 & 1.5 & 3.4 & 0.9 & 0.8 & 0.2 & 0.7 & 0.1 & 14.4 & 7.1 & 2.8 & 6.4 & 12.5 & 4.2 \\
\hline Other dinoflagellates & 0.6 & 0.1 & 0.0 & 0.0 & 0.2 & 0.0 & 0.0 & 0.0 & 0.2 & 0.1 & 0.0 & 0.3 & 0.2 & 0.1 \\
\hline Pseudo-nitzschia & & & & & & & & & & & & & & \\
\hline pseudodelicatissima & 29.3 & 1.6 & 61.7 & 63.0 & 49.2 & 0.1 & 0.0 & 0.1 & 0.8 & 0.6 & 0.1 & 0.0 & 0.0 & 0.0 \\
\hline Other diatoms & 9.6 & 1.1 & 20.8 & 19.6 & 8.1 & 0.7 & 0.0 & 0.1 & 1.7 & 0.5 & 2.8 & 0.9 & 0.0 & 0.0 \\
\hline
\end{tabular}


Table 2. Cell numbers (cells $\mathrm{l}^{-1}$ ) and carbon biomass $\left(\mu \mathrm{g} \mathrm{C}^{-1}\right.$ ) of all thecate heterotrophic dinoflagellates (THD) and of Protoperidinium steinii at $2 \mathrm{~m}$ depth

\begin{tabular}{|c|c|c|c|c|c|c|c|c|c|c|c|c|c|c|}
\hline Group or species & Sep 7 & Sep 14 & Sep 21 & Sep 25 & Sep 28 & Oct 5 & Oct 11 & Oct 13 & Oct 16 & Oct 20 & Oct 23 & Oct 26 & Oct 30 & Nov 1 \\
\hline (a) THD, cells ${ }^{-1}$ & 1590 & 258 & 299 & 152 & 187 & 24 & 23 & 78 & 916 & 2062 & 769 & 1426 & 3278 & 3158 \\
\hline (b) P. steinii, cells $1^{-1}$ & 750 & 127 & 123 & 41 & 35 & 1 & 2 & 6 & 529 & 1500 & 420 & 861 & 2091 & 2125 \\
\hline $\mathrm{b}$ as $\%$ of a & 47 & 49 & 41 & 27 & 19 & 4 & 9 & 8 & 58 & 73 & 55 & 60 & 64 & 67 \\
\hline (c) THD, $\mu \mathrm{g} \mathrm{C} \mathrm{l}^{-1}$ & 2.13 & 0.43 & 0.72 & 0.50 & 0.65 & 0.11 & 0.11 & 0.48 & 1.81 & 3.16 & 1.99 & 2.51 & 3.98 & 4.11 \\
\hline (d) P. steinii, $\mu \mathrm{g} \mathrm{C} \mathrm{l}^{-1}$ & 0.73 & 0.12 & 0.12 & 0.04 & 0.03 & 0.00 & 0.00 & 0.01 & 0.51 & 1.45 & 0.41 & 0.83 & 2.02 & 2.05 \\
\hline $\mathrm{d}$ as $\%$ of $\mathrm{c}$ & 34 & 29 & 16 & 8 & 5 & 1 & 2 & 1 & 28 & 46 & 20 & 33 & 51 & 50 \\
\hline
\end{tabular}

forme, and Oblea rotunda among the thecate heterotrophic dinoflagellates. In Fig. 3B, the dynamics of the $P$. divergens and $P$. pallidum populations (note the $10 \times$ expansion of the ordinate scale) are shown for comparison with those of $P$. steinii and P. pyriforme (Fig. 3A). There was no suggestion that either $P$. divergens or $P$. pallidum reacted positively to the Ceratium bloom.

Pallium feeding by Protoperidinium steinii on dinoflagellate prey, particularly on Ceratium furca, was observed on a number of occasions throughout the sampling period (Fig. 4, Table 4). Besides this, P. steinii was seen to capture a ciliate and to practice cannibalism (Table 4). Feeding by 2 or 3 cells on one and the same food item (Fig. 4C), as well as cannibalism, became more frequent as autotrophic food became depleted during prolonged incubation. More than one cell feeding on a common prey object has previously been noted in P. cf. divergens (Jeong 1994) and in the mixotrophic Fragilidium subglobosum (Skovgaard 1996). Although P. steinii was present in substantial numbers during the diatom bloom in September, it was never seen to feed on diatoms.
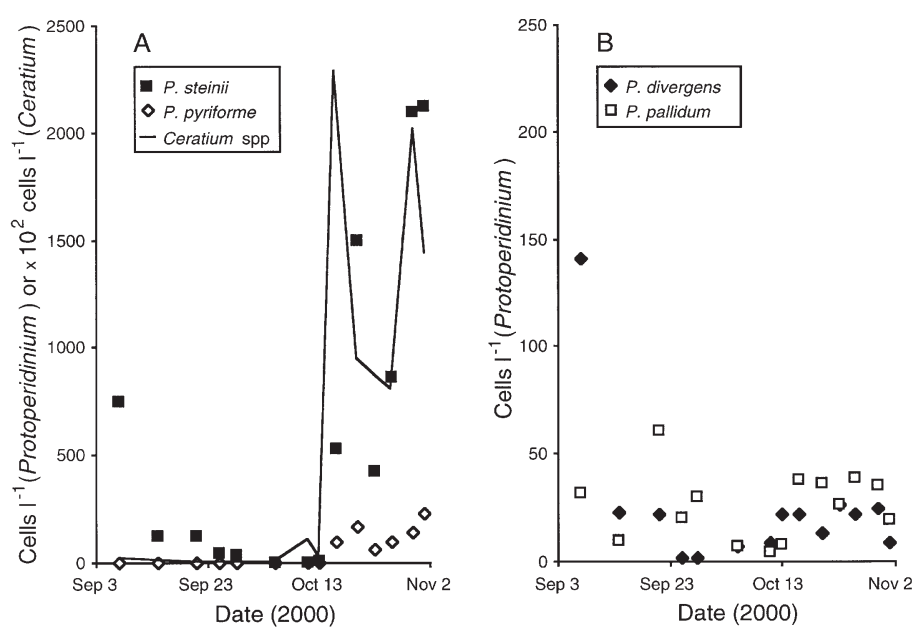

Fig. 3. Variations at $2 \mathrm{~m}$ depth in cell numbers of selected dinoflagellates. (A) Protoperidinium steinii (घ), P. pyriforme $(\diamond)$, and Ceratium spp. (-); note factor $\times 100$ for Ceratium spp. (B) P. divergens ( $\bullet$ ) and P. pallidum ( $\square$ ); note $10 \times$ expansion of ordinate scale in $\mathrm{B}$ relative to $\mathrm{A}$

\section{DISCUSSION}

Protoperidinium species and other heterotrophic dinoflagellates occurring in Scandinavian waters are generally eurythermal, except for a few cold-water forms restricted to winter and spring (Kjæret et al. 2000). Within the narrow temperature and salinity ranges of the present study, Protoperidinium population dynamics were in all likelihood governed by food availability.

A Pseudo-nitzschia pseudodelicatissima bloom in the Oslofjord in September and October 1994 encouraged population growth of Protoperidinium granii and

Table 3. Maximum cell numbers of heterotrophic dinoflagellates during the diatom bloom (September 21 to $28 ; 3$ dates) and the dinoflagellate bloom (October 16 to November 1; 6 dates)

\begin{tabular}{|lrr|}
\hline Species & Maximum cell number (cells l $^{-1}$ ) \\
& Sep 21-28 & Oct 16 to Nov 1 \\
\hline Protoperidinium spp. & & \\
P. bipes & 3 & 1 \\
P. brevipes & 0 & 90 \\
P. conicum & 65 & 8 \\
P. crassipes & 0 & 1 \\
P. curtipes & 0 & 74 \\
P. depressum & 0 & 10 \\
P. divergens & 22 & 26 \\
P. cf. excentricum & 0 & 13 \\
P. granii & 2 & 4 \\
P. oblongum & 2 & 6 \\
P. cf. ovatum & 0 & 1 \\
P. pallidum & 61 & 39 \\
P. pellucidum & 1 & 6 \\
P. pentagonum & 1 & 0 \\
P. punctulatum & 29 & 8 \\
P. pyriforme & 0 & 226 \\
P. steinii & 123 & 2125 \\
P. thorianum & 0 & 3 \\
P. sp. & 4 & 4 \\
Others & & 2 \\
Dinophysis hastata & 1 & 36 \\
D. rotundata & 13 & 24 \\
Diplopelta bomba & 4 & \\
Diplopsalis lenticula & 11 & \\
Oblea rotunda & 50 & \\
Zygabikodinium lenticulatum & 0 & \\
\hline
\end{tabular}


Table 4. Observed grazing incidents with Protoperidinium steinii as the grazer. The numbers are cumulate for the period September 7 to November 1

\begin{tabular}{|lc|}
\hline Prey type & $\begin{array}{c}\text { Number of } \\
\text { observed incidents }\end{array}$ \\
\hline Ceratium furca & 40 \\
C. tripos & 4 \\
C. fusus & 1 \\
C. lineatum & 1 \\
C. sp. & 5 \\
Dinophysis acuta & 1 \\
Prorocentrum micans & 1 \\
Protoperidinium steinii (cannibalism) & 2 \\
Unidentified dinoflagellate & 26 \\
Unidentified ciliate & 1 \\
Diatom & None \\
\hline
\end{tabular}

other Protoperidinium species likely to be diatom grazers (Kjæret et al. 2000). The diatom bloom in September 2000 may have been too weak or too short-lived to permit a similar situation to develop. By contrast, the massive Ceratium bloom in October was the probable reason for the increase in the Protoperidinium steinii population. Naustvoll (2000) previously showed that $P$. steinii requires dinoflagellate prey, in the form of Heterocapsa triquetra or Prorocentrum micans, for rapid growth in the laboratory. A similar convergence of field and laboratory observations exists for Protoperidinium cf. divergens and P. crassipes (Jeong \& Latz 1994), but not so far for any other Protoperidinium species specialized in dinoflagellate prey. There is no absolute requirement for dinoflagellate food in $P$. steinii, since it shows positive but slow growth on diatoms (Naustvoll 2000). It is noteworthy however that the initial fairly high $P$. steinii population in our study seemed to decline during the Pseudo-nitzschia bloom. Our observations on Protoperidinium pyriforme, together with the finding by Jacobson \& Anderson (1986) that it preferentially captures dinoflagellate prey, suggests that also the growth of this species is
Fig. 4. Grazing by Protoperidinium steinii (sampling date/observation date in parentheses) on: (A) on Ceratium furca cell (Oct 23/24); (B) on C. furca cell (Oct 16/18); (C) 3 cells on 1 C. furca cell (Nov 1/5); (D) on C. tripos cell (Oct 20/22); (E) on C. furca cell (Oct 30/Nov 1). Arrows indicate pallium stretched around the prey. Arrowheads in $\mathrm{C}$ and $\mathrm{E}$ indicate $P$. steinii. In E, an unidentified round object, unmarked, is inside the $C$. furca cell. Scale bars: $50 \mu \mathrm{m}$
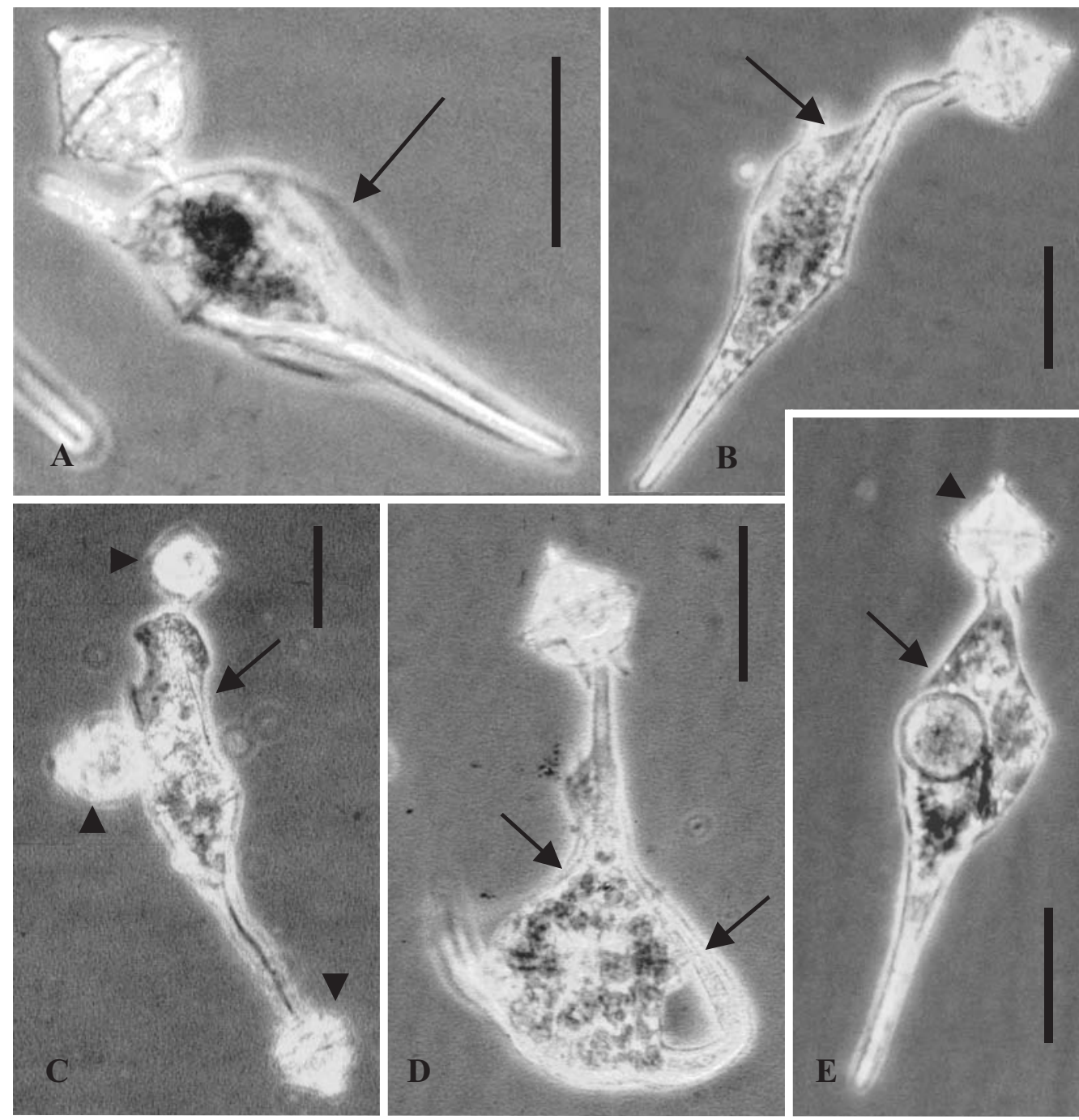
selectively promoted by dinoflagellate blooms. It may be significant that $P$. pyriforme is taxonomically close to $P$. steinii. The ability of these small predators to attack the much larger Ceratium spp. is remarkable in view of the failure of several common copepod species to feed on Ceratium cells, apparently because they are too large for them (Nielsen 1991).

Heterotrophic dinoflagellate population development has been shown to trail phytoplankton blooms by a few days (Nakamura et al. 1995, 1996, Tiselius \& Kuylenstierna 1996), suggesting an opportunistic strategy that restricts population growth to periods of prey abundance. Unfortunately, existing quantitative data on predator-prey relationships are equivocal. In published laboratory studies on Protoperidinium spp., maximum growth rates were achieved only at food concentrations of 250 to $400 \mu \mathrm{g} \mathrm{C}^{-1}$ (Buskey et al. 1994, Buskey 1997) or higher (estimated from data in Jeong \& Latz 1994). In P. steinii feeding on the dinoflagellate Heterocapsa triquetra, food saturation of

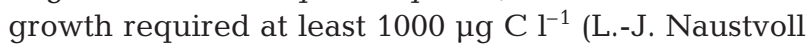
unpubl. data). Estimated phytoplankton biomasses during the Ceratium bloom, though exceptionally high for the Oslofjord, were well below this level. It seems unlikely that Protoperidinium populations should be permanently barred from realizing their inherent growth potential. This seeming discrepancy between field and laboratory data can only be resolved by further research. It should be noted that the increase in abundance of $P$. steinii from October 13 to October 20 (Fig. 3A) is likely to reflect advection and patchiness as much as it reflects net growth: the increase corresponds to a growth rate of $>1$ division $\mathrm{d}^{-1}$, much higher than the highest growth rates measured by Naustvoll (2000) in laboratory experiments on this species.

The failure of Protoperidinium pallidum to respond to the Ceratium bloom is in agreement with experimental results indicating that this species cannot utilize dinoflagellate food for growth (Naustvoll 2000). In the case of $P$. divergens, it is less easy to account for the lack of a positive response. In the Oslofjord (Kjæret et al. 2000), and in Danish waters (Hansen 1991), this species is usually associated with late-summer biomass maxima of autotrophic dinoflagellates, including Ceratium spp. Growth of Oblea rotunda appeared to be stimulated during the Ceratium bloom, but no grazing incidents involving this species were observed. It may have fed on Prorocentrum micans which was present during the bloom and which has been shown to serve as excellent food for it (Strom \& Buskey 1993).

Interactions between grazers and their prey are among the main factors responsible for the structuring of the planktonic food web. Although the standing stocks of heterotrophic dinoflagellates in our study were too small to have an impact on the autotrophic biomass, our data underline the high degree of grazing selectivity in Protoperidinium species. Effects such as those reported here may contribute to the remarkable species diversity in the marine microplankton. The extreme complexity of the microplanktonic food web is also shown by the fact that the main prey in the present investigation, Ceratium furca, can act as a predator on ciliates (Bockstahler \& Coats 1993, Smalley et al. 1999).

Acknowledgements. We thank 4 anonymous referees for their constructive criticism of the manuscript.

\section{LITERATURE CITED}

Archer SD, Leakey RJG, Burkill PH, Sleigh MA (1996) Microbial dynamics in coastal waters of East Antarctica: herbivory by heterotrophic dinoflagellates. Mar Ecol Prog Ser 139:239-255

Bockstahler KR, Coats DW (1993) Spatial and temporal aspects of mixotrophy in Chesapeake Bay dinoflagellates. J Eukaryot Microbiol 40:49-60

Buskey EJ (1997) Behavioral components of feeding selectivity of the heterotrophic dinoflagellate Protoperidinium pellucidum. Mar Ecol Prog Ser 153:77-89

Buskey EJ, Coulter CJ, Brown SL (1994) Feeding, growth and bioluminescence of the heterotrophic dinoflagellate Protoperidinium huberi. Mar Biol 121:373-380

Fritz L, Triemer RE (1985) A rapid simple technique utilizing Calcofluor White M2R for the visualization of dinoflagellate thecal plates. J Phycol 21:662-664

Hansen PJ (1991) Quantitative importance and trophic role of heterotrophic dinoflagellates in a coastal pelagial food web. Mar Ecol Prog Ser 73:253-261

Hansen PJ, Calado AJ (1999) Phagotrophic mechanisms and prey selection in free-living dinoflagellates. J Eukaryot Microbiol 46:382-389

Jacobson DM, Anderson DM (1986) Thecate heterotrophic dinoflagellates: feeding behavior and mechanism. J Phycol 22:249-258

Jeong HJ (1994) Predation by the heterotrophic dinoflagellate Protoperidinium cf. divergens on copepod eggs and early naupliar stages. Mar Ecol Prog Ser 114:203-208

Jeong HJ (1999) The ecological roles of heterotrophic dinoflagellates in marine planktonic community. J Eukaryot Microbiol 46:390-396

Jeong HJ, Latz MI (1994) Growth and grazing rates of the heterotrophic dinoflagellates Protoperidinium spp on red tide dinoflagellates. Mar Ecol Prog Ser 106:173-185

Kjæret AH, Naustvoll LJ, Paasche E (2000) Ecology of the heterotrophic dinoflagellate genus Protoperidinium in the inner Oslofjord (Norway). Sarsia 85:453-460

Lessard EJ (1991) The trophic role of heterotrophic dinoflagellates in diverse marine environments. Mar Microb Food Webs 5:49-58

Matsuyama Y, Miyamoto M, Kotani Y (1999) Grazing impact of the heterotrophic dinoflagellate Polykrikos kofoidii on a bloom of Gymnodinium catenatum. Aquat Microb Ecol 17:91-98

Menden-Deuer S, Lessard EJ (2000) Carbon to volume relationships for dinoflagellates, diatoms, and other protist plankton. Limnol Oceanogr 45:569-579

Nakamura Y, Suzuki S, Hiromi J (1995) Population dynamics of heterotrophic dinoflagellates during a Gymnodinium 
mikimotoi red tide in the Seto Inland Sea. Mar Ecol Prog Ser 125:269-277

Nakamura Y, Suzuki S, Hiromi J (1996) Development and collapse of a Gymnodinium mikimotoi red tide in the Seto Inland Sea. Aquat Microb Ecol 10:131-137

Naustvoll LJ (2000) Prey size spectra and food preferences in thecate heterotrophic dinoflagellates. Phycologia 39: $187-198$

Nielsen TG (1991) Contribution of zooplankton grazing to the decline of a Ceratium bloom. Limnol Oceanogr 36:1091-1106

Skovgaard A (1996) Engulfment of Ceratium spp (Dinophyceae) by the thecate photosynthetic dinoflagellate Fragilidium subglobosum. Phycologia 35:490-499

Smalley GW, Coats DW, Adam EJ (1999) A new method using fluorescent microspheres to determine grazing on ciliates

Editorial responsibility: Otto Kinne (Editor),

Oldendorf/Luhe, Germany by the mixotrophic dinoflagellate Ceratium furca. Aquat Microb Ecol 17:167-179

Strathmann RR (1967) Estimating the organic carbon content of phytoplankton from cell volume or plasma volume. Limnol Oceanogr 12:411-418

Strickland JDH, Parsons TR (1972) A practical handbook of seawater analysis, 2nd edn. Bull Fish Res Board Can 167:1-310

Strom SL, Buskey EJ (1993) Feeding, growth, and behavior of the thecate heterotrophic dinoflagellate Oblea rotunda. Limnol Oceanogr 38:965-977

Tiselius P, Kuylenstierna M (1996) Growth and decline of a diatom spring bloom: phytoplankton species composition, formation of marine snow and the role of heterotrophic dinoflagellates. J Plankton Res 18:133-155

Submitted: March 12, 2001; Accepted: June 12, 2001

Proofs received from author(s): December 18, 2001 